\title{
Bazı İleri Kademe Kışlık Kolza (Brassica napus L.) Hatlarının Edirne Koşullarında Verim ve Verim Unsurlarının Belirlenmesi
}

\author{
Sami SÜZER \\ Trakya Tarımsal Araştırma Enstitüsü, Edirne \\ Sorumlu yazar e-posta (Corresponding author e-mail): suzersami@yahoo.com
}

Öz

Bu araştırma, Trakya Tarımsal Araştırma Enstitüsünde geliştirilen bazı ileri kademe kışlık kolza (Brassica napus L.) hatlarının Edirne koşullarında verim ve verim unsurlarının belirlenmesi amacıyla yapılmıştır. Denemeler, tesadüf blokları deneme desenine göre 4 tekrarlamalı olarak 2012-2013 ve 2013-2014 kışlık kolza yetiştirme dönemlerinde Edirne'de Trakya Tarımsal Araştırma Enstitüsü arazisinde yürütülmüştür. Çalışmada kışıı kolza materyali olarak dört adet ileri kademe hat (TK-05-10, TK-05-12, TK-05-14, TK-0520) ve dört adet tescilli standart çeşit (Süzer, Excalibur, Elvis, NK-Petrol) olmak üzere toplam 8 genotip kullanılmıştır. Bu araştırmada dekardan alınan tane veriminin yanında yağ oranı, yağ verimi, bin tane ağırlığı, bitki çıkış tarihi, kışa dayanma, bitki boyu, yan dal sayısı, bitkide harnup sayısı, harnupta tane sayısı, harnup çatlama \%'si, tam çiçeklenme tarihi, fizyolojik olum tarihi, yatma ve hasatta tanede \% nem değerleri belirlenmiştir. İki yıl süre ile Edirne koşullarında yapılan bu araştırmadan elde edilen verilerin analiz ve değerlendirme sonuçlarına göre, denemeye alınan ileri kademe hat ve çeşitler arasında dekardan alınan tane verim farkı istatistiksel açıdan \%0.01 düzeyinde önemli bulunmuştur. Denemesi yapılan bu 8 ileri kademe kolza hat ve çeşidinin tam çiçeklenme tarihi 9-17 Nisan, fizyolojik olum tarihi 3-10 Haziran, bitki boyu 170$190 \mathrm{~cm}$, bitkide harnup sayısı 126-164, harnupta tane sayısı 22-26, harnup çatlatma oranı \%0-5, dekara tane verimi $286.0-350.3 \mathrm{~kg} / \mathrm{da}$ arasında değişmiştir.

Anahtar Kelimeler: Kolza, Brassica napus L., hat, verim, yağ

\section{Determination of Yield and Yield Components of Some Advanced Rapeseed (Brassica napus L.) Varieties in Edirne Conditions}

\begin{abstract}
This research was carried out to determine of yield and yield components of some advanced rapeseed (Brasicca napus L.) varieties in Trakya Agricultural Research Institute-Edirne conditions. The experiments were established in randomized complete block design with 8 varieties in four replications. The research lasted for two growing seasons from 2012 to 2014. As a material totally 8 genotypes' 4 advanced lines' TK05-10, TK-05-12, TK-05-14, TK-05-20 and 4 certified standard varieties' Süzer, Excalibur, Elvis, NK-Petrol winter rapeseed varieties are used in the experiment. Observations and evaluations were made for grain yield/ha, seed oil content $\%$, oil yield/ha, 1000 seed weight, full plant emerge date, cold tolerance, plant height, branch number, capsule number in per plant, seed number per capsule, capsule crack \%, first flowering date, plant lodging, and percent seed moisture in harvest. According two growing season results of this research in Edirne conditions, it has been found statistically significant $(0.01 \%)$ seed yield differences among advanced lines and certified varieties. Whole flowering date 9 to 17 April, physiological maturity date 3 to 10 June, plant height 170 to $190 \mathrm{~cm}$, capsule number per plant 126 to 164 , seed number per capsule $22-26$, pods cracking 0 to $5 \%$, and seed yield per hectare 2860 to $3503 \mathrm{~kg}$ were changed among eight rapeseed advanced lines and varieties.
\end{abstract}

Keywords: Rapeseed, Brasicca napus L., line, yield, oil 


\section{Giriş}

$\mathrm{K}$ olza (Brassica napus L.), dünyada en önemli yemeklik yağ bitkilerinden biridir. Dünyada kolza üretimi FAO 2013 yılı istatistiklerine göre 72.532.995 ton ile yağlı tohumlu bitkiler arasında soyadan sonra ikinci sırada yer almaktadır. Türkiye'de ise kanola, rapiska, rapitsa isimleriyle de bilinen kolzanın kışlık ve yazlık olmak üzere iki formu bulunmaktadır. Ülkemizde daha çok kışlık kolza üretimi 102.000 ton ile 2000'li yıllarda önemli artış göstererek çoğunlukla Trakya bölgesinde ekim alanı bulmuştur. Ancak, Türkiye'de yağlı tohumlu bitkiler üretimi ulusal tüketim için yeterli değildir ve intiyacımızın yaklaşık \%50'si yurt dışından ithal edilmektedir (Karaosmanoğlu, 1999; Kolsarıcı ve ark. 2005; Süzer 2012; Anonim 2013).

Ürün olarak hasat edilen kolza tohumlarında, çeşit özelliğine ve yetişme koşullarına bağlı olarak yaklaşık \%38-50 arasında yağ bulunmaktadır. Kolza tohumlarından yağ çıkarıldıktan sonra geriye kalan küspesi ise \%29.5 ile \%57.5 arasında protein içerdiğinden değerli bir hayvan yemidir. Ayrıca kolza, bal arılarını cezbeden ve ilkbaharda erken açan sarıçiçekleriyle arıcılar için de polen ve nektar kaynağı olarak değerli bir bitkidir (Öğütçü ve Kolsarıcı 1979; Mag 1990; Süzer 2014).

Soğuğa dayanıklı, yağ oranı yüksek yeni kışlık çeşitlerin geliştirilmesiyle kolza tarımı en fazla Trakya olmak üzere Güney Marmara, Karadeniz ve İç Anadolu'nun geçit bölgelerinde ekim nöbetine girmeye başlamıştır. Dünyada birçok ülkede kolza, ekim nöbetine girdiği tarım arazilerinde toprağın organik maddece zenginleşmesine ve verimliliğinin korunmasına yardımcı olan iyi bir ön bitkidir. Serin iklim tahıllarından önce ekim nöbetinde kolza yer alırsa toprağın yapısının iyileşmesine ve bazı kök hastalıklarını baskı altına alarak azalmasına yardımcı olmaktadır. Tarım topraklarının üretim gücünün korunması ve sürdürülebilir tarım açısından da her bölgenin yetişen ana ürünleri arasında kolza ekim nöbetinde yer almalıdır (Arnaud 1989; Angus et al. 1994; Kirkegaard et al. 1994; Guy 1995; Guy and Gareau 1998; Süzer 2008; Süzer 2009; Burbulus ve ark. 2008).

Başalma (2004), farklı orijinli kışlık kolza (Brassica napus ssp. oleifera. L.) çeşitlerinin
Ankara koşullarında verim ve verim öğelerinin karşılaştırdığı araştırmada, Almanya orijinli 16 kışlık kolza çeşidi (Atilla, Alaska, İris, Orabel, Pronto, Wotan, Express, Lisabel, Apex, Magnum, Alpine, Orkan, Mohican, Oxident, Artus ve Lirajet), Danimarka orijinli 2 kışlık kolza çeşidi (Chang ve Hansen), 6 Fransa orijinli kışlık kolza çeşidi (Licord, Liberator, Bristol, Capitol, Contact ve Samurai) ve 1 Amerika orijinli kışlık kolza (Cescade) çeşidi olmak üzere toplam 25 kışlık kolza çeşidini 1999-2000 ve 2000-2001 yıllarında denemeye almıştır. En yüksek tane verimi, 2000 yılında 265.00 kg/da ile Contact çeşidinden, 2001 yılında ise 301.33 kg/da ile Licord çeşidinde alınırken, her iki yılın ortalamasına göre en yüksek tohum verimi 263.83 kg/da ile yine Licord çeşidinden elde edilmiştir. Benzer olarak en yüksek yağ verimi, 2000 yılında $114.10 \mathrm{~kg} / \mathrm{da}$ ile Contact çeşidinden, 2001 yılında ise 136.67 kg/da ile Licord çeşidinde belirlenirken, her iki yılın ortalamasına göre en yüksek yağ verimi 114.98 $\mathrm{kg} /$ da ile yine Licord çeşidinde saptanmıştır.

Atakişi (1991), bugün özellikle Kanada ve Batı Avrupa ülkelerinde ıslah edilmiş erüsik asitsiz, yağ ve protein oranı yüksek kolza çeşitlerinin ekildiğini, kolza yağ besin değeri ve içeriğinin zeytinyağı ve yerfıstığı yağının kalitesinde olduğu, dünya kolza üretiminin \%90'ından fazlası da artık insan beslenmesinde kullanıldığını ifade etmiştir.

İnan ve Gaytancıoğlu (1996), Trakya bölgesinde sayıları 54'e varan çeşitli kapasitelerde olmak üzere 2 milyon tonun üzerinde ayçiçeği tohumu işleyebilecek yağ fabrikalarının bulunduğunu, bu fabrikaların sahip oldukları kapasitenin ülkemiz bitkisel yağ ihtiyacının tamamını işleyebilecek hatta ihracat yapabilecek düzeyde olduğu, hâlbuki ülkemiz ayçiçeği üretiminin 700-800 bin ton civarında gerçekleşmekte olduğu ve her yıl yurtdışından yağ ithal etmek zorunda kaldığımızı, ayrıca bu yağ fabrikalarının hammadde yetersizliğinden kapasitelerinin ancak \%30-40'ını kullandığını ifade etmişlerdir.

Süzer (2007), Edirne koşullarında 20022006 yılları arasında üç yıl süreyle Egc-102, Embleme, Elvis, Likord, Licrown, Bristol, Eldo, Jura ve Capitol olmak üzere 9 kanola çeşidi ile tesadüf blokları deneme desenine göre 4 
tekrarlamalı olarak yaptığı araştırma sonucunda, üç yıl ortalaması olarak söz konusu 9 çeşit arasında çeşitlerin ilk çiçeklenme tarihleri 4-14 nisan, fizyolojik olum tarihleri 7-19 haziran, bitki boyları $125-150 \mathrm{~cm}$, bitkilerde harnup sayıları 119-129, harnuplarda tane sayıları 22-26, harnup çatlatma oranı \%1-10 ve dekara tane verimleri 202.3 - $284.7 \mathrm{~kg} / \mathrm{da}$ arasında olduğunu belirlemiştir.

Bu araştırma, Trakya Tarımsal Araştırma Enstitüsünde geliştirilen bazı ileri kademe kışlık kolza hatlarının, Edirne koşullarında verim ve verim unsurlarını doğal yağış koşullarında belirlemek amacıyla yapılmıştır.

\section{Materyal ve Yöntem}

$\mathrm{Bu}$ araştırmanın materyalini, Trakya Tarımsal Araştırma Enstitüsü Kolza Islah Projesi çalışmaları çerçevesinde geliştirilen dört adet ileri kademe hat; TK-05-10, TK-05-12, TK-0514, TK-05-20 ve dört adet tescilli standart çeşit; Süzer, Excalibur, Elvis, NK-Petrol olmak üzere 8 farklı kışlık genotip oluşturmuştur. Denemeler, tesadüf blokları deneme desenine göre 4 tekrarlamalı olarak 2012-2013 ve 2013-2014 kışlık kolza yetiştirme dönemlerinde Edirne'de 2 yıl süreyle Trakya Tarımsal Araştırma Enstitüsü arazisinde yürütülmüştür (Yurtsever, 1984). Denemelerin ekimi Eylül ayı sonunda el ile açılan sıralara yapılmıştır. Parsel boyutları, ekimde $5.00 \mathrm{~m} \times 1.75 \mathrm{~m}=8.75 \mathrm{~m} 2$ (5 sıra), hasatta $5.0 \times 1.06 \mathrm{~m}=5.30 \mathrm{~m} 2$ (3 sıra), sıra arası $35 \mathrm{~cm}$ olarak alınmıştır. Deneme alanının toprağı her yıl analiz yaptırılarak tavsiyeler doğrultusunda ekimden önce toprak hazırlığında dekara 20 kg, 20-20-0 kompoze, şubat ayında dekara $20 \mathrm{~kg} / \mathrm{da}$ amonyum sülfat $(\% 21 \mathrm{~N})$ ve mart ayı içeresinde $20 \mathrm{~kg} / \mathrm{da}$

Çizelge 1. 2012/2013-2013/2014 kışlık kolza yetişme dönemlerine ait deneme yeri toprak analiz sonuçları (*) Table 1. Soil analyses results of the experimental area for 2012/2013-2013/2014 winter rapeseed growing seasons

\begin{tabular}{ccccccccc}
\hline Yıl & $\begin{array}{c}\text { Derin- } \\
\text { lik } \\
(\mathrm{cm})\end{array}$ & $\begin{array}{c}\text { Su ile \% } \\
\text { Doymuşluk }\end{array}$ & $\mathrm{pH}$ & Bünye & $\begin{array}{c}\text { Alınabilir } \\
\mathrm{P}_{2} \mathrm{O}_{5} \\
(\mathrm{ppm})\end{array}$ & $\begin{array}{c}\text { Alınabilir } \\
\mathrm{K}_{2} \mathrm{O} \\
(\mathrm{ppm})\end{array}$ & $\begin{array}{c}\text { Alınabilir } \\
\text { Çinko } \\
(\mathrm{ppm})\end{array}$ & $\begin{array}{c}\text { Organik } \\
\text { Madde } \\
(\%)\end{array}$ \\
\hline $2012-13$ & $0-30$ & 52.000 & 6.800 & Killi-Tınlı & 10.700 & 330.000 & 1.150 & 1.300 \\
$2013-14$ & $0-30$ & 51.000 & 6.600 & Killi-Tınlı & 10.500 & 320.000 & 1.120 & 1.200 \\
\hline
\end{tabular}

${ }^{*}$ Toprak analizleri Edirne Ticaret Borsasında yaptırılmıştır.

*Soil analyses were done at Edirne Commodity Exchange

Çizelge 2. 2012/2013-2013/2014 kışlık kolza yetişme dönemine ait ortalama bazı iklim değerleri (*) Table 2. Meteorological data for 2012/2013-2013/2014 winter rapeseed growing seasons (*)

\begin{tabular}{|c|c|c|c|c|c|c|}
\hline \multirow[b]{2}{*}{ AYLAR } & \multirow{2}{*}{$\begin{array}{c}\text { Uzun Yıllar } \\
\text { Ortalama } \\
\text { Yağış } \\
(\mathrm{mm})\end{array}$} & \multirow{2}{*}{$\begin{array}{c}\text { Aylık Yağış } \\
\text { Miktarı } \\
(\mathrm{mm})\end{array}$} & \multirow{2}{*}{$\begin{array}{l}\text { Aylık Nispi } \\
\text { Nem(\%) }\end{array}$} & \multicolumn{3}{|c|}{ Sıcaklık $\left({ }^{\circ} \mathrm{C}\right)$} \\
\hline & & & & Minimum & Maksimum & Ortalama \\
\hline Ekim 2012 & 52.9 & 46.1 & 73.3 & 5.7 & 34.0 & 18.9 \\
\hline Kasim 2012 & 72.4 & 12.4 & 83.4 & -0.9 & 24.0 & 12.2 \\
\hline Aralik 2012 & 61.7 & 165.8 & 92.7 & -6.2 & 17.6 & 3.6 \\
\hline Ocak 2013 & 48.1 & 134.6 & 90.2 & -7.7 & 18.2 & 4.2 \\
\hline Şubat 2013 & 46.9 & 104.5 & 88.3 & -0.7 & 18.8 & 6.8 \\
\hline Mart 2013 & 52.2 & 62.9 & 77.0 & -1.7 & 23.6 & 9.8 \\
\hline Nisan 2013 & 51.0 & 51.0 & 73.2 & 4.0 & 32.0 & 12.7 \\
\hline Mayis 2013 & 56.0 & 11.0 & 66.7 & 4.9 & 32.9 & 20.8 \\
\hline Haziran 2013 & 41.5 & 26.6 & 70.1 & 11.4 & 36.2 & 23.3 \\
\hline Toplam & 482.7 & 614.9 & 92.7 & -7.7 & 36.2 & 12.4 \\
\hline Ekim 2013 & 52.9 & 30.7 & 77.5 & -1.6 & 26.8 & 12.8 \\
\hline Kasim 2013 & 72.4 & 73.9 & 86.7 & -2.4 & 23.4 & 11.0 \\
\hline Aralik 2013 & 61.7 & 2.3 & 82.2 & -5.6 & 12.1 & 2.7 \\
\hline Ocak 2014 & 48.1 & 74.9 & 87.4 & -4.2 & 17.3 & 5.5 \\
\hline Şubat 2014 & 46.9 & 3.8 & 86.0 & -4.4 & 20.2 & 7.6 \\
\hline Mart 2014 & 52.2 & 124.5 & 81.4 & -1.4 & 23.7 & 10.1 \\
\hline Nisan 2014 & 51.0 & 36.8 & 81.6 & -0.1 & 25.5 & 13.6 \\
\hline Mayis 2014 & 56.0 & 61.7 & 76.6 & 4.0 & 32.1 & 18.6 \\
\hline Haziran 2014 & 41.5 & 68.8 & 73.8 & 10.3 & 33.6 & 22.9 \\
\hline Toplam & 482.7 & 477.4 & 78.78 & -5.6 & 33.6 & 12.59 \\
\hline
\end{tabular}

*İklim verileri Edirne Meteoroloji Müdürlüğünden alınmıştır

*Meteorological data is obtained from Edirne Meteorology Directorate 
amonyum nitrat $(\% 26 \quad \mathrm{~N})$ gübreleri uygulanmıştır (Süzer, 2010; Süzer, 2012; Süzer 2014). Bu araştırmada dekardan alınan tane veriminin yanında yağ oranı, yağ verimi, bin tane ağırlığı, bitki çıkış tarihi, kışa dayanma, bitki boyu, yan dal sayısı, bitkide harnup sayısı, harnupta tane sayısı, harnup çatlama \%'si, tam çiçeklenme tarihi, fizyolojik olum tarihi, yatma ve hasatta tanede $\%$ nem değerleri belirlenmiştir.

Deneme yeri topraklarından her yıl alınan örneklerin analiz sonuçları Çizelge 1'de verilmiştir. Toprakların analiz sonuçlarından anlaşılacağı üzere deneme toprakları ince bünyeli, organik madde içeriği düşük, fosforca orta, potasyumca zengin, killi tınlı, kireçsiz kahverengidir. Söz konusu bu toprakların organik madde içeriği \%1.20 - 1.30 fosfor oranı $\left(\mathrm{P}_{2} \mathrm{O}_{5}\right) 10.50$ - $10.70 \mathrm{ppm}$, potasyum oranı $\left(\mathrm{K}_{2} \mathrm{O}\right)$ 320-330 ppm ve pH derecesi 6.60 - 6.80 arasındadır. Çizelge 2'de araştırmanın yapıldığı yıllarda aylara göre düşen yağış miktarları gösterilmiştir.

Söz konusu bu çizelgeden görüldüğü gibi 2012-2013 kışlık kolza yetiştirme döneminde düşen toplam yağış miktarı $614.9 \mathrm{~mm}$ ile uzun yıllara göre yaklaşık \%27 daha yüksek olurken, 2013-2014 döneminde düşen toplam yağış miktarı ise $477.4 \mathrm{~mm}$ ile uzun yıllar ortalaması civarında gerçekleşmiştir. Minimum sıcaklığın her iki kolza yetişme döneminde de kışın en fazla $-7.7{ }^{\circ} \mathrm{C}$ olması, bitkilerin ekim başında erken ekimle kışa kuvvetli kök ile 6-8 yaprak arası rozet döneminde girdiğinden donmamıştır. Deneme parsellerinden elde edilen verim değerlerinin varyans analizleri JMP 5.0.1 istatistik programı (Anonim, 2002) ile yapılmıştır. Konular arasında etkili farkları bulmak için F-testinin \%1 ve \%5 düzeyi kullanılmıştır. Ortalama değerler arasındaki karşılaştırmalar, Asgari Önemli Fark (AÖF) testine göre \%5 olasılıkla yapılmıştır (Little and Hills 1977; Yurtsever 1984).

\section{Bulgular ve Tartışma}

Çizelge 3' de kolza verim denemelerine ait 2012-2014 yılları arası iki yıllık ortalama dekardan alınan tane verimi, yağ oranı, yağ verimi ve bin tane ağırık değerleri verilmektedir. Bu çizelgeden de görülebileceği gibi denemede yer alan 4'ü ileri kademe hat ve 4'ü tescilli standart çeşit olmak üzere toplam 8 kolza genotipi arasında dekardan alınan tane ve yağ verimi ile tanedeki yağ oranları arasında istatistiksel açısından önemli ( $p \leq 0.01)$ farklar bulunmuştur. Bu araştırmada yer alan 8 kolza genotipinin dekardan alınan ortalama verimleri 2012-2013 döneminde $281.1 \mathrm{~kg} / \mathrm{da}$ ile 370.6 kg/da ve 2013-2014 döneminde 281.2 kg/da ile $395.1 \mathrm{~kg} / \mathrm{da}$ arasında değişmiştir. İki yıl ortalamasına göre ise denemeye giren çeşitler arasında dekardan alınan ortalama tane verimi $286.0 \mathrm{~kg} / \mathrm{da}$ ile $350.3 \mathrm{~kg} / \mathrm{da}$ arasında

Çizelge 3. Kışlık kolza verim denemelerine ait 2012/2013-2013/2014 yetişme dönemleri arası iki yıllık ortalama dekardan alınan tane verimi, tane yağ oranı, yağ verimi ve bin tane ağırlık değerleri

Table 3. 2 Years averages of grain yield/ha, seed oil content \%, oil yield/ha and 1000 seed weight of rapeseed for 2012/2013-2013/2014 winter growing seasons ( ${ }^{*}$ )

\begin{tabular}{|c|c|c|c|c|c|c|c|c|}
\hline \multirow{2}{*}{$\begin{array}{l}\text { Çeşit } \\
\text { No }\end{array}$} & \multirow[t]{2}{*}{ Çeşit Adı } & \multicolumn{2}{|c|}{$\begin{array}{l}\text { Dekara Verim } \\
(\mathrm{Kg} / \mathrm{da})\end{array}$} & \multirow{2}{*}{$\begin{array}{c}\text { İki Yıl } \\
\text { Ortalama } \\
\text { Verimleri } \\
\text { Kg/da) }\end{array}$} & \multirow[t]{2}{*}{$\begin{array}{l}\text { Verim } \\
\text { Sırası }\end{array}$} & \multirow{2}{*}{$\begin{array}{c}\text { İki Yıl } \\
\text { Ort. } \\
\text { Yağ } \\
\text { Oranı } \\
(\%)\end{array}$} & \multirow{2}{*}{$\begin{array}{c}\text { Dekara } \\
\text { Yağ } \\
\text { Verimi } \\
\text { (Kg/da) }\end{array}$} & \multirow{2}{*}{$\begin{array}{c}\text { İki Yıl } \\
\text { Ort. } \\
\text { Bin } \\
\text { Tane } \\
\text { Ağır. } \\
\text { (g) }\end{array}$} \\
\hline & & $\begin{array}{c}2012 / 13 \\
\text { YIlI } \\
\end{array}$ & $\begin{array}{c}2013 / 14 \\
\text { YIlı } \\
\end{array}$ & & & & & \\
\hline 1 & SÜZER(K) & 321.1 & 329.7 & $325.4 \mathrm{ABC}$ & 4 & 44.6 & 145.1 & 4.3 \\
\hline 2 & TK-05-10 & 300.7 & 362.6 & $331.7 \mathrm{AB}$ & 2 & 43.2 & 143.3 & 3.7 \\
\hline 3 & TK-05-12 & 300.5 & 335.8 & $318.2 \mathrm{CDE}$ & 5 & 45.9 & 146.1 & 4.5 \\
\hline 4 & TK-05-14 & 305.4 & 395.1 & $350.3 \mathrm{~A}$ & 1 & 47.4 & 166.0 & 4.5 \\
\hline 5 & TK-05-20 & 299.7 & 305.1 & 302.4 CDE & 6 & 45.0 & 136.1 & 4.3 \\
\hline 6 & EXCALIBUR(K) & 370.6 & 281.2 & $325.9 \mathrm{BCD}$ & 3 & 46.9 & 146.7 & 4.6 \\
\hline 7 & ELVIS (K) & 281.1 & 290.8 & $286.0 \mathrm{E}$ & 8 & 47.1 & 134.8 & 4.5 \\
\hline 8 & NK-PETROL(K) & 287.6 & 287.6 & $287.6 \mathrm{DE}$ & 7 & 45.8 & 131.7 & 4.2 \\
\hline Yılların & Verim Ortalaması & 308.3 & 326.3 & 314.5 & & & & \\
\hline A.Ö.F & LCD 0.05): & $26.5^{\star *}$ & $43.2^{* *}$ & $25.7^{* *}$ & & & & \\
\hline D.K (C & V.) $\%$ : & 5.8 & 9.1 & 7.5 & & & & \\
\hline
\end{tabular}

**0.01 düzeyinde istatistikî açıdan önemli

** Significant at 0.01 level 
değişmiştir. Edirne koşullarında yapılan bu araştırmada iki yıl ortalamasına göre dekardan alınan tane verimi bakımından TK-05-14 ileri kademe hattı $350.3 \mathrm{~kg} / \mathrm{da}$ ile birinci, TK05-10 hattı $331.7 \mathrm{~kg} / \mathrm{da}$ ile ikinci, standart Excalibur çeşidi 325.9 ile üçüncü, standart Süzer çeşidi $325.4 \mathrm{~kg} / \mathrm{da}$ ile dördüncü, TK-05-12 hattı 318.2 $\mathrm{kg} / \mathrm{da}$ ile beşinci, TK-5-20 hattı $302.4 \mathrm{~kg} / \mathrm{da}$ ile altıncı, standart NK-Petrol çeşidi $287.6 \mathrm{~kg} / \mathrm{da}$ ile yedinci ve standart Elvis çeşidi $286.0 \mathrm{~kg} / \mathrm{da}$ ile son sırayı almıştır. Kolza çeşitlerinin tanelerindeki $\% 7$ nem bazında iki yıl ortalaması yağ oranı \% 43.2 ile $\% 47.4$ arasında değişmiştir. Tanelerdeki ortalama yağ oranı açısından TK-5-14 leri kademe hattı \%47.4 ile birinci, standart Elvis çeşidi \%47.1 ikinci ve standart Excalibur çeşidi \%46.9 ile üçüncü olmuştur. İki yıl ortalamasına göre dekardan alınan ortalama yağ verimleri $131.7 \mathrm{~kg} / \mathrm{da}$ ile $166.0 \mathrm{~kg} / \mathrm{da}$ arasında değişmiştir. Dekardan alınan ortalama yağ verimi açısından TK-05-14 ileri kademe hattı $166.0 \mathrm{~kg}$ ile birinci, standart Excalibur çeşidi 146.7 ile ikinci, TK-05-12 ileri kademe hattı 146.1 ile üçüncü ve standart Süzer çeşidi 145.1 ile dördüncü sırayı almıştır. Süzer'in (2007) bazı farklı orijinli kışlık kolza (Brassica napus L.) çeşitleriyle Edirne koşullarında verim ve verim öğelerini karşılaştırdığı araştırmada elde ettiği sonuçlar burada bulunan sonuçlarla paralellik göstermektedir.

Araştırmada yer alan kolza çeşitlerinin bin tane ağırlıkları ortalama $3.7 \mathrm{~g}$ ile $4.6 \mathrm{~g}$ arasında değişmiştir. İki yıl ortalamasına göre Excalibur çeşidi $4.6 \mathrm{~g}$ ile birinci, TK-05-14 ve TK-05-12 hatları ile Elvis çeşidi $4.5 \mathrm{~g}$ ile ikinci ve Süzer çeşidi ise $4.3 \mathrm{~g}$ ile üçüncü sırayı almıştır. Çizelge 4' de kolza adaptasyon denemesinde yer alan 4'ü ileri kademe hat ve 4'ü tescilli çeşit olmak üzere toplam 8 kolza genotipinin dekardan alınan iki yıllık ortalama tam çiçeklenme ve fizyolojik olum tarihleri ile bitki boyu, kışa dayanma, yan dal sayısı, bitkide harnup sayısı, harnupta tane sayısı, \% harnup çatlama, yatma ve hasatta tanede \% nem değerleri verilmiştir. Denemeye alınan ileri kademe kolza hat ve standart tescilli çeşitler arasında iki yıl boyunca kışa dayanma 1-2, tam (ful) çiçeklenme tarihi 10-17 Nisan, fizyolojik olum tarihi 03-10 Haziran, bitki boyu 170-190 $\mathrm{cm}$, bitkide harnup sayısı 126-144, harnupta tane sayısı 22-26, yatma 1-3 arası, harnup çatlatma \% 1-5 ve hasatta tanede rutubet \% 78 arasında değişmiştir. Özgüven ve Kırıcı'nın (1999) Çukurova ve Başalma'nın (2004) Ankara koşullarında yaptıkları, bazı kolza çeşitlerinde verim ve verim unsurlarının belirlenmesi araştırmalarında elde ettikleri bulgular burada bulunan sonuçları desteklemektedir.

\section{Sonuç}

İki yıl süreyle Edirne koşullarında gerçekleştirilen bu araştırma sonucunda 4'ü ileri kademe hat ve 4'ü tescilli çeşit olmak üzere toplam 8 kolza genotipi arasında dekardan alınan ortalama tane verimi $286.0 \mathrm{~kg} / \mathrm{da}$ ile $350.3 \mathrm{~kg} / \mathrm{da}$ arasında değişmiştir. İki yıl ortalamasına göre 4'ü ileri kademe hat ve 4'ü tescilli çeşit olmak üzere 8 genotip arasında TK$05-14$ hattı $350.3 \mathrm{~kg} / \mathrm{da}$ tane verimi ile birinci, TK-05-10 hattı $331.7 \mathrm{~kg} / \mathrm{da}$ ile ikinci, Excalibur çeşidi $325.9 \mathrm{~kg} / \mathrm{da}$ ile üçüncü ve Süzer çeşidi $329.7 \mathrm{~kg} / \mathrm{da}$ ile dördüncü sırayı almıştır.

Çizelge 4. Kışlık kolza adaptasyon denemelerine ait 2012/2013-2013/2014 yetişme dönemleri arası iki yıllık ortalama bazı fenolojik ve fizyolojik gözlem ve ölçüm değerleri

Table 4. 2 Years averages of some phenological and physiological observations and measurements from winter rapeseed adaptation experiments 2012/2013-2013/2014

\begin{tabular}{|c|c|c|c|c|c|c|c|c|c|c|c|}
\hline $\begin{array}{l}\text { Sira } \\
\text { No }\end{array}$ & $\begin{array}{l}\text { Çeşit } \\
\text { Adı }\end{array}$ & $\begin{array}{l}\text { *Kışa } \\
\text { Dayan } \\
\text { ma } \\
(1-5)\end{array}$ & $\begin{array}{l}\text { Tam } \\
\text { Çiçeklen } \\
\text { me } \\
\text { Tarihi }\end{array}$ & $\begin{array}{l}\text { Fizyolojik } \\
\text { Olum } \\
\text { Tarihi }\end{array}$ & $\begin{array}{l}\text { Bitki } \\
\text { Boyu } \\
(\mathrm{cm})\end{array}$ & $\begin{array}{l}\text { Yan } \\
\text { Dal } \\
\text { Sayısı } \\
\text { (adet) }\end{array}$ & $\begin{array}{c}\text { Bitkide } \\
\text { Harnup } \\
\text { Sayısı } \\
\text { (adet) }\end{array}$ & $\begin{array}{c}\text { Harnup } \\
\text { Tane } \\
\text { Sayısı } \\
\text { (adet) }\end{array}$ & $\begin{array}{l}\text { Yatma } \\
(1-5)^{\star *}\end{array}$ & $\begin{array}{c}\text { Harnup } \\
\text { Çatlama } \\
(\%)\end{array}$ & $\begin{array}{c}\text { Hasat } \\
\text { Nem } \\
(\%)\end{array}$ \\
\hline 1 & SÜZER(K) & 1 & 11.04 .13 & 05.06 .13 & 170 & 6 & 140 & 24 & 1 & 0 & 7 \\
\hline 2 & TK-05-10 & 1 & 13.04 .13 & 08.06 .13 & 175 & 6 & 138 & 24 & 2 & 1 & 7 \\
\hline 3 & TK-05-12 & 1 & 10.04 .13 & 04.06 .13 & 190 & 6 & 136 & 22 & 2 & 0 & 7 \\
\hline 4 & TK-05-14 & 1 & 11.04 .13 & 08.06 .13 & 190 & 6 & 140 & 26 & 2 & 0 & 7 \\
\hline 5 & TK-05-20 & 1 & 15.04 .13 & 06.06 .13 & 170 & 6 & 134 & 24 & 2 & 0 & 7 \\
\hline 6 & EXCALIBUR(K) & 1 & 09.04 .13 & 03.06 .13 & 175 & 6 & 144 & 26 & 2 & 0 & 7 \\
\hline 7 & ELVIS (K) & 1 & 16.04 .13 & 09.06 .13 & 175 & 6 & 130 & 24 & 2 & 5 & 7 \\
\hline 8 & NK-PETROL(K) & 2 & 17.04 .13 & 10.06.13 & 180 & 6 & 126 & 22 & 3 & 5 & 8 \\
\hline
\end{tabular}

*: 1.dayanıklı, 2. orta, 5.hassas, **: 1.yatma yok, 5.yatma var

*: 1.resistant, 2.average, 5.sensitive, **: 1.No Lodging, 5.Severe Lodging 
Araştırmada yer alan 4'ü ileri kademe hat ve 4'ü tescilli çeşit olmak üzere toplam 8 kolza genotipinin iki yıl ortalaması yağ içeriği \%43.3 ile \%47.4 arasında değişmiştir. Tanelerdeki ortalama yağ oranı açısından TK-05-14 hattı \%47.4 ile birinci, Elvis çeşidi \%47.1 ile ikinci, Excalibur çeşidi \%46.9 ile üçüncü ve TK-05-12 hattı \%45.9 ile dördüncü sırayı almıştır. İki yıl ortalaması olarak dekardan alınan yağ verimleri $131.7 \mathrm{~kg} / \mathrm{da}$ ile $166.0 \mathrm{~kg} / \mathrm{da}$ arasında değişmiştir. Ortalama olarak dekardan alınan yağ verimi açısından TK-05-14 çeşidi 166.0 kg/da ile birinci, Excalibur çeşidi 146.7 ile ikinci, TK-05-12 hattı 146.1 kg/da ile üçüncü ve Süzer çeşidi $145.1 \mathrm{~kg} / \mathrm{da}$ ile dördüncü sırayı almıştır. Sonuç olarak iki yıl süre ile Edirne koşullarında yapılan bu araştırmadan elde edilen verilerin analiz ve değerlendirme sonuçlarına göre 4'ü ileri kademe hat ve 4'ü tescilli çeşit olmak üzere toplam 8 kolza genotipi arasında dekardan alınan tane verim farkı istatistiksel açıdan $\% 0.01$ düzeyinde önemli bulunmuştur. Denemeye alınan ileri kademe hat ve çeşitler arasında kışa dayanma 1-2, tam (ful) çiçeklenme tarihi 10-17 Nisan, fizyolojik olum tarihi 03-10 Haziran, bitki boyu 170-190 cm, bitkide harnup sayısı 126-144, harnupta tane sayısı 22-26, yatma 1-3 arası, harnup çatlatma $\% 1-5$ ve hasatta tanede rutubet $\% 7-8$ ve ortalama tane verimi $286.0 \mathrm{~kg} / \mathrm{da}$ ile 350.3 kg/da arasında değişmiştir.

\section{Kaynaklar}

Angus J. F., Gardner P. A., Kirkegaard J. A., Desmarchelier J. M., 1994. , Biofumigation: Isothiocyanates released from Brassica roots inhibit the growth of the take-all fungus. Plant and Soil 162, 107-112

Anonim 2002. JMP ${ }^{\circledR}$ Design of Experiments, Version 5.0.1.2, SAS Institute Inc., Cary, NC. USA.

Anonim 2013. FAOSTAT $^{\odot}$ FAO Statistics Division 2015 | 15 June 2015

Arnaud F., 1989. "L'evoution des surfaces et des varietes de colza en France" Colza d'hiver 1989/90, France

Atakişi İ., 1997. Yağ Bitkileri Yetiştirme ve Islahı. T.Ü Tekirdağ Ziraat Fakültesi Yayınları, Yayın No: 148 Ders Kitabı: 10 Tekirdağ

Başalma D., 2004. Kışlık Kolza (Brassica napus ssp. oleifera L.) Çeşitlerinin Ankara Koşullarında Verim ve Verim Öğeleri Yönünden Karşılaştırılması. Ankara Üniv. Zir. Fak. Tarla Bitkileri Böl., Tarım Bilimleri Cilt 10: Sayı:2 Ankara
Burbulus N., Kuprienè R., Blinstrubienè A., 2008. Investigation of cold resistance of winter rapeseed in vitro. Sodininkystè ir daržininkystè 27:223-232

Guy S., Gareau R., 1998. Crop rotation, residue durability, and nitrogen fertilizer effects on winter wheat production. Journal of Production Agriculture 11, 457-461

İnan İ.H., Gaytancıoğlu O., 1996. Türkiye'de ayçiçeği tarımı ve bitkisel yağ sanayiinin ekonomik yapısı, T.Ü. Tekirdağ Ziraat Fakültesi Dergisi, Cilt: 4, Tekirdağ

Karaosmanoğlu F., 1999. Vegetable oil fules: a review. Energy Sources, 21(3):221-231

Kirkegaard J. A., Gardner P. A., Angus J.F., Koetz E., 1994. Effect of Brassica crops on the growth and yield of wheat. Australian Journal of Agricultural Research 45, 529-545

Kolsarıcı Ö., Gür M.A., Kaya M.D., İşler N. ve Başalma D., 2005. Yağlı Tohumlu Bitkiler Üretimi. VI.Türkiye Ziraat Mühendisliği Teknik Kongresi I. Cilt 3-7 Ocak, Ankara, 41-62

Little T. M., and Hills F. S., 1978. Agricultural Experimentation. Design and Analysis. University of California. Riverside, California, U.S.A. pp:87-100

Mag T.K., 1990. Further Processing of Canola And Rapeseed Oils. Ch.15 In Canola And Rapeseed: Production, Chemistry, Nutrition, and Processing Technology, F. Shahidi (Ed.), p. 251-276. Van Nostrand Reinhold, New York

Öğütçü Z. ve Kolsarıcı Ö., 1979. Kolzanın (Brassica napus L.) Yetiştirme Tekniği ve Islahı. $44 \mathrm{~S}$. Ankara

Özgüven M., Kırıcı S., 1999. Bazı kolza çeşitlerinin Çukurova bölgesinde verim ve verim komponentlerinin belirlenmesi. Ç.Ü. Ziraat Fakültesi Dergisi 14: 41-48

Süzer S., 2007. Bazı Kolza (Kanola) Çeşitlerinin Edirne Koşullarında Verim Ve Verim Unsurlarının Belirlenmesi. 1.Ulusal Yağlı Tohumlu Bitkiler ve Biyodizel Sempozyumu. 28-31 Mayıs 2007, Samsun

Süzer S., 2007. Türkiye'de Kolzanın (Brassica napus ssp. oleifera L.) Ekim Nöbetindeki Yeri Ve Üretim Olanakları. 1.Ulusal Yağlı Tohumlu Bitkiler ve Biyodizel Sempozyumu. 28-31 Mayıs 2007, Samsun. S: 277-283

Süzer S., 2008. Kolza (Kanola) Tarımı. Hasad Yayıncılık Ltd. Şti. İstiklal Mah. Birlik Cad. No:13/B Ümraniye, İstanbul

Süzer S., 2009. Kanola (Kolza) Tarımında Verimi Etkileyen Faktörler Ve Gübreleme. Hasad Bitkisel Üretim Dergisi. 24(285):78-84 
Süzer "Bazı Illeri Kademe Kışlık Kolza (Brassica napus L.) Hatlarının Edirne Koşullarında Verim ve Verim Unsurlarının Belirlenmesi"

Süzer S., 2010. Effects of Potassium Fertilization on Sunflower (Helianthus annuus L.) and Canola (Brassica napus ssp. oleifera L.) Growth. Proceedings of the Regional Workshop of the International Potash Institute held at Antalya, Turkey, 22-25 Nov

Süzer S., 2012. Kanola Yetiştiriciliği. Tarım Gündem Dergisi. 2(10):70-72
Süzer S., 2014. Effects Of Plant Nutrition On Canola (Brassica napus L.) Growth. Balkan Agriculture Congress 08-11 September 2014, Edirne, Turkey

Yurtsever N, 1984. Deneysel İstatistik Metotlar. Tarım Orman ve Köyişleri Bakanlığı Köyhizmetleri Genel Müd. Yayınları. Genel Yayın No:121. teknik Yayın No:56. Ankara 